\title{
The Effectiveness of Interpersonal Communication through Coaching Method for Employee in RSUD R. Syamsudin, SH
}

\author{
${ }^{1}$ Widiana Latifah, ${ }^{2}$ Nani Nurani Muksin \\ Universitas Muhammadiyah Jakarta, Kota Tanggerang Selatan, Banten, Indonesia \\ E-mail: 1f_widiana@yahoo.co.id, 2naninuranimuksin@umj.ac.id
}

\begin{abstract}
In the era of globalization marked by intense competition between hospitals, it is necessary to anticipate an increase in service quality on an ongoing basis in line with higher customer expectations for hospital services. Top management of RSUD R. Syamsudin, S.H. Sukabumi City has determined the policy of coaching method as a mean of interpersonal communication among the leader and staffs to increase the motivation and as part of the staff development efforts, since nowadays the hospital staffs are required to have high motivation to work to perform in health service. The purpose of this study was to determine how the effectiveness of interpersonal communication affects the success of the coaching method. This research was conducted using a qualitative descriptive method. Data were collected through in-depth interviews with two coaches and one coachee. The results showed that the effectiveness of interpersonal communication in the coaching method affected the success of the coaching process. Openness is marked by the coachee's willingness, to be honest, and open with the coach, empathy is carried out by active listening and clarifying, a supportive attitude is carried out through self-disclosure and powerful questions, a positive attitude is carried out by building trust and acceptance of positive thoughts and equality which is marked by eliminating the position subordinate superiors and the form of conversation in the form of dialogue and discussion.
\end{abstract}

Keywords: Coaching, Interpersonal Communication, Motivation

\section{INTRODUCTION}

The climate of competition has had a positive impact on advances in health services in Indonesia. This condition has a consequence that hospital managers must be able to face various challenges and provide excellent service for patients. In the era of globalization marked by intense competition between hospitals, it is necessary to anticipate an increase in service quality on an ongoing basis in line with higher customer expectations for hospital services. Based on the research results, without high motivation from employees to work for the benefit of the organization, the goals that have been set are difficult to achieve. Motivation has a positive and significant effect on employee performance at Regional
General Hospital (RSUD) Dokter Soedarso, Pontianak (Potu, 2013).

To increase the work spirit of employees in an organization, effective communication between management and employees is needed. According to research (Anaomi, 2014), communication errors that occur between management and employees can cause the delivery of messages not on target and resulting in differences of understanding. It can be caused by differences in knowledge, needs, and values that the management believes in.

Communication is an integral part of a management process, organizational members need to communicate with each other because harmonious cooperation to achieve goals can be developed through 
effective communication (Bacal, 2012). This communication can be interpreted as verbal or non-verbal communication, which contains opinions, ideas, ideas, and information.

So far, the development or coaching of RSUD R. Syamsudin, SH Sukabumi City employees has mostly used training methods to increase knowledge, changing attitudes, and efforts to improve skills only.

Efforts that need to be made to employees of RSUD R. Syamsudin, SH to encourage increased work motivation lies in a personal communication approach, so the psychological intervention method implemented is the career development coaching method. Research (Kuswarno, 2001) states that communication styles determine the effectiveness of organizational communication in line with research (Sunarto, 2008) which states that communication effectiveness will occur when accompanied by conducive openness that is accommodated by an institution that works systematically, meaning that building interpersonal communication within the organization is a way for management to build a good organizational environment. Through communication, the information obtained is also broader and more diverse, considering that communication is a process of sharing and exchanging ideas, information, knowledge, attitudes, or feelings between individuals and groups that aim to create an activity (Liliweri, 2015).

Coaching is defined by the International Coach Federation (ICF), as a form of partnership with clients through a process that stimulates/provokes thoughts and creative processes that inspire clients to increase their personal and professional potential (Whitmore, 2017). The partnership means that a coach and coachee are a form of collaboration where both are equal partners who maintain the neutrality of the relationship and respect each other. The coaching method is interpersonal communication that contains elements of communication, namely sender of messages, messages, media, the receiver of messages, and feedback. Coaching is carried out between two parties, namely the sender of the message known as the coach and the receiver of the message known as the coachee.

The steps involved in implementing Coaching (Salim, 2015) are 1) Building Trust is done quickly and simply through communication. Several things need to be known to build a good relationship effectively, namely with 3 communication devices, namely: Content, Body Posture and Facial Expression, Voice Pitch and Volume. 2) Active Listening. When we become active listeners, we can easily influence, negotiate, and establish communication. Plus, active listening can avoid misunderstandings. 3) Clarifying with the aim of clarity of conversation, the clarification step aims to help find problems. Clarifying can also avoid creating ambiguous meanings that can confuse and lead to misunderstanding. 4) Asking Right Questions, the right questions can help reveal the real problem, answer and overcome the problems faced by clients/employees. According to De Vito (Liliweri, 2015), interpersonal communication or interpersonal communication is the sending of messages from someone that is received by another person with direct effects or feedback.

Meanwhile, (Effendy, 2014) defines interpersonal communication or interpersonal communication as communication between a sender of the message and a receiver of the message. This type of interpersonal communication is considered the most effective in changing human attitudes, opinions, or behavior because it is caused by a 
dialogical interpersonal communication process. De Vito in (Liliweri, 2015) states that if interpersonal communication is to run effectively, then interpersonal communication must have five aspects of communication effectiveness, 1) Openness, namely the willingness of the receiver of the message to react honestly to the stimulus that comes and openness to those who invite to interact. 2) Empathy, namely placing ourselves as the sender of messages emotionally and intellectually in the position of receiver of the message. 3) Supportiveness is aimed at reducing the defensive attitude of communication which is an aspect of communication effectiveness. 4) Positiveness. The sender of messages who have a positive selfattitude will communicate positive things. This can be triggered by encouragement (stroking), namely the behavior of encouraging someone to respect others. 5) Equality or equality is the recognition that both parties have something equally important to say. Equality also means the same, equality, position, and so on, which makes the flow of interpersonal communication acceptable to both parties.

The absence of harmonious communication within the organization will lead to failure in achieving the goals of the organization. If an employee has problems in the form of feeling uncomfortable with the leader, then the employee will have less motivation to work, so that the organizational goals will not be achieved. Motivation has a root word from the Latin word movore, which means motion or the urge to move(Prawira, 2014). Motivation according to (Danim, 2012) is defined as encouragement, strength, enthusiasm, need, pressure, or psychological mechanisms that can encourage a person or group of people to achieve performance according to what is expected, cognitively, motivation is defined as individual activities to determine the basic framework of goals and define behavior as a means of achieving these goals. Affectionately, motivation can be interpreted as an attitude and/or basic values possessed by a person or group of people doing or not doing something. Motivation is further defined as a complex force that can get someone to start something and maintain working conditions in the organization.

The top management of RSUD R. Syamsudin, SH, Sukabumi City determined the coaching method policy as a way of communicating between personal management to employees to increase motivation and as an effort to improve employee performance. The application of a transformational management style is reflected in the coaching method which is defined as a partnership in an in-depth conversation process to generate thought and creative thinking, which inspires to maximize personal potential and professionalism (Kurnia P., 2012). Similar to research (Munthe, 2015) which examines the application of coaching as a current management style, a manager by taking an approach as a coach will be able to improve performance and at the same time develop subordinates by improving abilities and motivation. Both studies only discuss coaching as a management style that can increase work motivation, while this study was conducted to determine how the effectiveness of interpersonal communication affects the success of the coaching method implemented to increase employee motivation.

\section{METHOD}

In this research, the approach used is a qualitative descriptive approach. Disclosure of data and facts used by researchers is in a non-statistical or nonsystematic form. Qualitative research seeks to understand and explain reality and try to assemble and arrange patterns to find something new or theory through a scientific induction process. In qualitative 
research, we are dealing with broad exposure (Bajari, 2017).

Qualitative methods have behavioral observation procedures and are described in writing or orally, the process is through data collection, analysis, and interpretation, then closes with drawing conclusions based on the data analysis (Moleong, 2010).

Research "The Effectiveness of Interpersonal Communication In Coaching Method Employees of RSUD R. Syamsudin, SH" seeks to reveal indepth the effectiveness of interpersonal communication that occurs in the coaching method. Data collection techniques in obtaining data used in the preparation of this study were primary and secondary data collection, namely: (1) The primary data obtained by researchers is from indepth interviews with informants who are the research subjects, namely two management who act as coaches; and one employee who acts as a coachee (2) Secondary data, namely the source of research data taken indirectly through intermediary media (obtained and recorded by other parties), namely from documents and literature studies, both published and unpublished. This research also goes through a triangulation process, besides that it is also analyzed based on the theories used in this study.

\section{RESULTS AND DISCUSSION}

RSUDR Syamsudin, S.H. Sukabumi

City is a regional public hospital owned by the Sukabumi City Government as well as a public service institution for the community in the field of referral health from the Sukabumi City, Sukabumi Regency, Bogor Regency, Lebak Regency, and Cianjur Regency. Serving patients with a capacity of approximately 700 beds certainly has its consequences for the development of the hospital in serving patients. As an institution of the Regional Government of Sukabumi City,
RSUD R. Syamsudin, SH of Sukabumi City also has the task of providing health services, namely carrying out services, promotion, prevention, recovery, healing, rehabilitation, referral services, and education in the health sector according to laws and regulations,

This condition in turn encourages employee performance, It's because employee performance is believed to be an important factor for overall organizational performance. The human resources in RSUD R. Syamsudin, SH Sukabumi City consist of health personnel including medical personnel (doctors), paramedics (nurses), non-nursing staff (pharmacists, health analysts, pharmacist assistants, nutritionists, physiotherapists, radiographers, and recorders. medical), and non-health personnel (finance, administration, personnel).

The management of RSUD R. Syamsudin, SH, Sukabumi City applies the coaching method as a way of communicating between personal management to employees to increase motivation and as an effort to improve employee performance. This is as expressed by (Griffin, 2012) "Like charades, interpersonal communication is a mutual, ongoing process of sending, receiving, and adapting verbal and nonverbal messages with another person to create and alter the images in both our minds.

Based on the results of the interview, the coaching held at RSUD R. Syamsudin, SH was limited to work problems and in applying the coaching method currently RSUD R. Syamsudin, SH Sukabumi City has 3 (three) top management as professional coaches have taken training as professional coaches at the Loop International of Coaching institution. Employees who have participated in coaching are still limited to structural and functional officials, equivalent to the head of the installation and head nurse. 
The coach, which consists of the board of directors, seeks to help employees solve these problems, refocusing employees on performance targets to be achieved by reinforcing to foster self-motivation.

Based on the results of the study, the coaching method contains an interpersonal communication component. There are coach and coachee, messages from both parties, the media used are the five senses because it is a face-to-face communication method and feedback as a measure of the success of communication. While the elements of the effectiveness of interpersonal communication through the coaching method are reflected in each coaching step in the form of building trust, active listening, clarifying, and asking the right question.

\section{Openness in Coaching Methods}

Based on the results of the interview, in the coaching process, there must be cooperation, good relationships, openness, honesty based on the commitment between the coach and coachee. Openness refers to the openness and willingness of employees as coachees to react honestly to stimuli that come and the openness of interpersonal communication participants to people who invite them to interact. For this reason, the first stage of implementing the coaching method is building trust. The coach must be able to convince the coachee that coaching is confidential then the coach must be able to build intimacy. The coach must be able to explain that in coaching, the positions of "leader" and "subordinate" must be removed first so that there is no doubt the coachee will say what he wants to convey. This is done to obtain transparency or self-disclosure from the coachee. The absence of openness is a barrier to the self-disclosure process.

To build openness, the coach must also create a comfortable and friendly atmosphere when conducting interviews.
Such as making a sitting position that is not intimidating, making small talk, and informal communication styles that create a comfortable and familiar atmosphere. Openness in employee coaching is beneficial for management to find out the existing problems experienced by the coachee as a subordinate in their work so that they can take steps or not continue to solve these problems.

\section{Empathy in the Coaching Method}

According to (Liliweri, 2015), when we empathize with someone, that person will more freely express his feelings and think about the future, he feels confident because you "put" your heart in his heart. Empathy is the ability for a person to put himself in someone else's shoes and understand feelings from another person's perspective. Empathy emphasizes the importance of sensing other people's feelings as a basis for building healthy interpersonal relationships. In empathy, attention can be done with emotion recognition. The more a person knows his own emotions, the more skilled he is at reading other people's emotions. Based on the results of the interview, in coaching, this is done so that the coach can respond appropriately and see everything from the coachee's point of view. Self-empathy can be communicated in 2 ways, namely verbally and non-verbally.

Verbally, the coach can show empathy with words, expressions, mumbles, and nonverbally, the coach can show empathy by showing the other person through physical closeness, facial expressions and appropriate gestures, maintaining eye contact and caring posture. . Empathy in the coaching process is found in Active Listening and Clarifying activities. During coaching, the coach must also have the ability to listen with the "third ear", so that the coach is able to capture messages or understand the coachee's feelings that are not conveyed verbally. In line with research (Maharani, 
2018) that having the optimal ability to listen and feel, in the end, there is a sense of mutual respect and respect so that they work together well and in a friendly way.

Clarification is the affirmation of a statement or response pattern in the form of a technique of responding to a conversation by clarifying the words that have been spoken through picking or taking the core of a conversation that is considered important which is restated (Lutfi, 2008). The clarifying step in the coaching process must be carried out by the coach while listening actively to what is conveyed by the coachee so that he gets an overall understanding and can show his understanding. Clarification can also be a stimulus for the coach to speak more clearly so that there are no misunderstandings. Clarifying can also be done by making affirmations or sharpening important things expressed by the coachee, repeating foreign terms or languages expressed by the coachee but not understood by the coach to avoid misunderstandings.

\section{Supporting Attitude in the Coaching Method}

The third aspect of the effectiveness of interpersonal communication is supportive attitudes. One of the ways to establish communication is because of mutual support (Rakhmat, 2012). The two parties who communicate must each commit to supporting open communication. The receiver of the message must respond spontaneously. To make a problem find a solution, it takes mutual support. This attitude can also make people act as expected and allow people to express their feelings in a good communication atmosphere. People tend to want to do self-disclosure to people who provide a positive and supportive attitude.

Supported by Jack Gibb (De Vito, 2011) it is stated that open and empathic communication cannot take place in an unsupportive atmosphere. This means that to make other people feel valued and interact more openly requires a person's ability to convey feelings and perceptions to others without judging, praising, or criticizing.

The results of the study illustrate that in the coaching held at RSUD R. Syamsudin, SH, Sukabumi City, there is mutual support between the management as a coach and the employee as a coachee. Coachee expresses his supportive attitude with openness (self-disclosure) and answers the coach's questions spontaneously. The coach's supportive attitude is carried out by providing stimulus and feedback on what the coachee has conveyed through empowering questions known as powerful questions and showing that the coach appreciates every coachee's answer.

At this stage, the process of strengthening the coachee's responses is formed until the coachee's solutions arise to the problems, belief in desires so that motivation arises from within him. The role of the coach here is not only to ensure that the coachee finds answers to problems or goals he wants to achieve, but the coach also ensures that it is implemented by the coachee through concrete actions so that in the end it is able to optimize the personal potential of the coachees. For this reason, a commitment is made to carry out continuous coaching so that the frequency of coaching for each person is different according to their needs.

\section{Positive Attitude in the Coaching Method}

A positive attitude in interpersonal communication can communicate positive things. In interpersonal communication, a positive attitude refers to 2 (two) aspects, namely: first, if a person has a positive view of himself then communication will develop. Second, if someone has a 
positive view of others it can also make communication develop. A positive attitude in interpersonal communication can be communicated in at least two ways, namely showing a positive attitude and positively encouraging people who are in the interaction.

The positive attitude that the coach must take is to build trust or building trust in the coachee so that that the coaching conversation is confidential

. Likewise, the coachee must have positive feelings or attitudes, the coachee must understand and accept with positive thoughts the stimulus that comes from the coach so that feedback can be received without being influenced by emotions. With an attitude like this, it can create effective communication so that the success rate of coaching can be achieved.

Honesty can also be an indicator of the coachee's positive attitude. With honesty from the coachee, the coach will easily make reinforcement of the ideas, opinions, problems faced, formulate action plans, and what goals the coachee wants to achieve until finally, it can increase motivation at work.

\section{Equality in Coaching Methods}

Equality in communication can be interpreted as an acknowledgment that each party has something equally important to convey. Equality contains elements that can make the flow of interpersonal communication acceptable to both senders of messages and receivers of messages. The effectiveness of interpersonal communication must be supported by equality so that there is an implicit and explicit recognition that each party has an alignment of values and prices. For interpersonal communication to achieve its efficiency, equality of education level, social level, economy, status, fate, struggle need to be considered in the topic of conversation.

In the coaching method, "partnership with clients" is one of the keywords contained in the ICF-based coaching definition, it states that the coaching process must be based on equality between coach and coachee. This is very important to support the coachee's confidence and familiarity with his coaches so that open communication is very effective which is useful for the success of the coaching process itself (Whitmore, 2017). In coaching, a coach and coachee stand the same height and sit the same low, side by side and relate like two close friends: trusting each other, being open, honest, what they are, not judging, not blaming, not reprimanding, not confronting, willing to learn, willing grow, and want to achieve something maximally and satisfactorily, for the advancement and development that coachee dreams of or hopes for.

The coaching method carried out at RSUD R. Syamsudin, SH, sometimes the position becomes an obstacle to selfdisclosure because the one who acts as a coach is the leader so that there is a feeling of reluctance in expressing feelings and desires of the coachee as subordinates. Other efforts are made to create a friendly atmosphere, both parties are in the same position, and get rid of feelings of embarrassment, both parties make a time contract that is adjusted to the coachee's condition, empowering the mind with the form of dialogue, discussion, question, and answer, use the term "brother" between coach and coachee.

\section{CONCLUSION}

Based on the description above, it can be concluded that the management of RSUD R. Syamsudin, SH Sukabumi City implements interpersonal communication through the employee coaching method. This is done to help employees solve problems at work, refocus employees on performance targets to be achieved to increase motivation at work. To improve 
overall hospital performance, this coaching method should be applied to all employees and carried out continuously.

Comparing the research results with the theory of the effectiveness of interpersonal communication, it can be concluded that the success of the coaching method cannot be separated from the elements contained in the theory.

The effectiveness of interpersonal communication in the coaching method in the aspect of openness refers to the openness and willingness from the coachee as receiver of the message, giving honestly to the stimulus provided by the coach. The aspect of empathy is pursued by active listening and clarifying activities, then the aspect of a supportive or supportive attitude is expressed by the coachee's self-disclosure and answers the coach's questions spontaneously. The coach's supportive attitude is carried out by providing stimulus and feedback on what the coachee has conveyed through empowering questions or known as powerful questions. A positive attitude aspect is carried out by the coach by building trust with the coachee

Coachee's positive attitude is characterized by honesty and understanding and accepting with positive thoughts all stimuli from the coach so that they can be accepted without affecting emotions. The aspect of equality in coaching is characterized by efforts that create equality between the coach and the coachee so that there is no distance in communication between the coach and the coachee because sometimes, between management and staff positions can become a barrier to communication because of a culture of people who are always reluctant to come forward to people in higher positions

It takes a high commitment from both parties to carry out the effectiveness of interpersonal communication in the coaching method to optimize the benefits of coaching and have an influence on the quality of coaching implementation.

\section{REFERENCES}

Anaomi. (2014). Strategi Komunikasi Persuasif Human Resources Development Dalam Menyelesaikan Konflik Karyawan Pt. Dimas Drillindo Cabang Duri Provinsi Riau. Jurnal Online Mahasiswa.

Bacal, R. (2012). Performance Management. Gramedia Pustaka.

Bajari, A. (2017). Metode Penelitian Komunikasi. Remaja Rosdakarya.

Danim, S. (2012). Motivasi Kepemimpinan dan efektifitas Kelompok. Rineka Cipta.

De Vito, J. A. (2011). Komunikasi Antar Manusia. Kharisma Publishing Group.

Effendy, O. U. (2014). Dinamika Komunikasi. Remaja Rosdakarya.

Griffin, E. M. (2012). A First Look At Communication Theory Eighth Edition. The McGraw-Hill Companies, Inc.

Kurnia P. (2012). Coaching Yang MenumbuhKembangkan (Pionir Jaya (ed.)).

Kuswarno, E. (2001). Efektivitas Komunikasi Organisasi. Mediator: Jurnal Komunikasi.

Liliweri, A. (2015). Komunikasi Antar Personal. Prenadamedia Grup.

Lutfi, F. (2008). Teknik-Teknik Komunikasi Untuk Konselor. UPTBK UM.

Maharani, D. (2018). Manajemen Komunikasi pada Petugas Kebersihan Kota Palembang. Mediator: Jurnal Komunikasi, 11(1), 119-128. https:// doi.org/10.29313/mediator.v11i1.3267

Moleong, L. J. (2010). Metode Penelitian Kualitatif. Remaja Rosdakarya.

Munthe, R. G. (2015). Menerapkan Coaching Sebagai Gaya Kepemimpinan Masa Kini. Jurnal Manajemen, 14(2).

Potu, A. (2013). Kepemimpinan, Motivasi dan Lingkungan Kerja Pengaruhnya Terhadap Kinerja Karyawan Pada Kanwil Ditjen Kekayaan Negara Suluttenggo Dan Maluku Utara di Manado. Jurnal Riset Ekonomi, Manajemen, Bisnis Dan Akuntansi, 
Widiana Latifah, et al. The Effectiveness of Interpersonal Communication through...

1(4). https://doi.org/10.35794/emba. v1i4.2894

Prawira, P. A. (2014). Psikologi Pendidikan dalam Perspektif Baru. Ar-Ruzz Media.

Rakhmat, J. (2012). Psikologi Komunikasi. Remaja Rosdakarya.

Salim, G. (2015). Effective Coaching. Bhuana Ilmu Populer.

Sunarto, S. (2008). Pengaruh Komunikasi dan Motivasi Kerja Aparatur terhadap Kualitas Pelayanan sertifikat Tanah. Mediator: Jurnal Komunikasi, 9(2), 403-414. https://doi.org/10.29313/ mediator.v9i2.1124

Whitmore, S. J. (2017). Coaching for Performance; Principles and Practice of Coaching and Leadership. Nicholas Brealey Publishing. 